\title{
The Study of Concentrations of Some Heavy Metals in Relation to Size of Macrobrachium vollenhovenii (Herklots, 1857) in Asejire Lake, Oyo State, Southwest Nigeria
}

\author{
Abayomi Abdul-Azeez Jimoh ${ }^{1}$, Abiodun Ojesanmi ${ }^{1}$, Rasaq Adewale Olowu ${ }^{2}$
}

${ }^{1}$ Department of Fisheries,

Faculty of Science,

Lagos State University, Nigeria

${ }^{2}$ Department of Chemistry,

Faculty of Science,

Lagos State University, Nigeria

\section{Correspondence}

Abayomi Abdul-Azeez Jimoh, Department of Fisheries, Faculty of Science, Lagos State University, Nigeria

email: abayomi.jimoh@lasu.edu.ng

\begin{abstract}
:
Introduction: Heavy metals are useful for essential animal tissue metabolism; however, when these metals exist beyond the permissible limits, they cause ecological damage and constitute threat to human health. Freshwater prawns, including Macrobrachium vollenhovenii, are bio-indicators of metal pollution. $M$. Vollenhovenii is an important source of protein and abundant in the Asejire Lake, which serves as a major source of drinking water to people living around the Lake.

Aims: This study was therefore designed to examine the concentrations of some heavy metals ( $\mathrm{Mn}, \mathrm{Pb}, \mathrm{Cd}, \mathrm{Cu}$ and $\mathrm{Zn})$ in water, sediment and different sizes of Macrobrachium vollenhovenii in Asejire Lake, southwest Nigeria.

Materials and Methods: Quarterly sampling of $M$. vollenhovenii, water and sediment was conducted on Asejire Lake in the months of November, February and May 2014. Analysis of the selected heavy metals in the various samples was done using Atomic Absorption Spectrophotometer. Bioaccumulation Factors (BAF) of the metals were also determined.

Results: Heavy metals concentration in prawns was in this order: $\mathrm{Zn}>\mathrm{Cu}$ $>\mathrm{Mn}>\mathrm{Pb}>\mathrm{Cd}$. Ranked mean concentration of heavy metals in different prawn sizes was large $>$ small $>$ medium. There was no significant difference, at $P=.05$, among heavy metals concentrations in different prawn sizes, except in Cadmium. $\mathrm{Pb}, \mathrm{Cu}$ and $\mathrm{Zn}$ were detected in water, while all the five metals were detected in sediment. Large prawns bioaccumulated the most heavy metals while medium prawns bioaccumulated the least. Cu was the most bioaccumulated heavy metal. Concentrations of $\mathrm{Mn}, \mathrm{Pb}, \mathrm{Cu}$ and $\mathrm{Cd}$ were above the $\mathrm{FAO}$ limit for prawn; concentrations of $\mathrm{Cu}$ and $\mathrm{Zn}$ in water were below the WHO limit, while $\mathrm{Pb}$ was above the limit. Concentrations of heavy metals in sediment were lower than the FAO limits.

Conclusion: These results suggest that prawns and water from Asejire Lake are not safe for human consumption, and it is recommended that proper managerial policy be put in place to check the influx of these metals into the Lake.

Keywords: Heavy Metals, Size, Macrobrachium vollenhovenii, Asejire Lake
\end{abstract}




\section{INTRODUCTION}

The existence of heavy metals in aquatic environment has been fundamentally traced to some naturally occurring geochemical resources. Anthropogenic activities such as untreated effluent and waste from industries, farms and communities discharged to water bodies have also contributed greatly to the persistence of heavy metals in aquatic environment $[1,2,3]$. Heavy metals when exist beyond the acceptable range in the aquatic ecosystem tends to bio-accumulate in aquatic organisms such as fish, shrimps and prawns over the time. Deposited metals in the aquatic environment, have been reported to accumulate in the food chain [4, $5,6,7]$. These metals cause ecological damage and also constitute serious threat to human health. However, many heavy metals are useful for essential animal tissues metabolisms when exist within the tolerable range.

Zinc is an essential trace element in living organisms, being involved in nucleic acid synthesis and occurs in many enzymes [8]. Background values of zinc in natural inland surface waters may vary from $0.001-0.2 \mathrm{mg} / \mathrm{L}$ or even higher [9]. High levels of zinc in the aquatic environment have been reported to be particularly toxic to crustaceans and mollusks [10]. Copper, an essential micronutrient for fish and aquatic life, is also widely used as an effective algaecide and molluscicide [11]. This metal is introduced into the aquatic environment through municipal waste waters, manure, fertilizers, antifouling paints and industrial wastes [12]. Despite its important role in the growth of most aquatic organisms, copper may become toxic to aquatic organisms when the level exceeds a specific threshold [13]. Lead is a highly toxic metal whose high concentration in the aquatic environment is attributed to industrial effluents and emissions from mechanized boats used for fishing and transportation purposes. Organic lead compounds are extensively used as an additive in petrol and this releases $\mathrm{Pb}$, which is not easily biodegradable, into the aquatic environment through drainage and surface runoffs [8]. Lead is a cumulative poison which inhibits the synthesis of hem in organisms where it interferes with the effective utilization of iron and blood circulation [12]. Manganese plays an important biological role in organisms, however, excess amount of manganese is toxic and the nervous system has been reported to be the most vulnerable. Cadmium, a highly toxic metal, with no known physiological role in aquatic organisms [14] enters aquatic bodies through run-offs from agricultural lands, degraded batteries, PVC plastics and ceramic industries.

Fin and shell fishes have been used as biological indicators of metal pollution of aquatic environments and suitability of these aquatic environments for human use [15]. As a result of their feeding habits, freshwater prawns have the ability to bio-accumulate metals from both water and sediment, and as such are one of the major bio-indicators of pollution in the aquatic environment. Freshwater prawns are decapod crustaceans belonging to the Palaemonidae family. With the exception of Europe, freshwater prawns have distribution across the tropics and subtropics on all continents [16]. The freshwater prawn, Macrobrachium vollenhovenii, is one of the important artisanal shellfishes in Nigeria; it serves as an important protein source for Nigerians and also of great aquaculture potential. Asejire Lake in Oyo State, southwest Nigeria serves as a major source of drinking water to several Nigerians in Ibadan (Oyo State) and some other towns in neighbouring Osun State; in addition, there is an abundance of Macrobrachium fishery in Asejire Lake. Consequent upon the abundance of this prawn in Asejire Lake and the hydrological importance of this lake to the people of Ibadan and surrounding towns/villages, this study aimed at determining the concentration of some selected heavy metals in relation to size of $M$. vollenhovenii in Asejire Lake. In addition, this study aimed to establish whether the concentrations of these selected heavy metals in $M$. vollenhovenii in Asejire Lake are within the acceptable range as recommended by the World Health Organization.

\section{MATERIALS AND METHODS}

\subsection{Description of the Study Area}

The Asejire Lake, latitude $7^{\circ} 22^{\prime} \mathrm{N}$ and longitude $4^{\circ} 08^{\prime} \mathrm{E}$ [17], was created by damming the Osun River, at Asejire, near lkire in the southwestern part of Nigeria. The lake has a total surface area of $23.69 \mathrm{~km}^{2}$ with a maximum depth of $19 \mathrm{~m}$ and length of $13 \mathrm{~km}$. The Lake receives water mainly from Rivers Osun and Oba, while the major outflowing river is the River Oshun. It serves as a major source of drinking water to several Nigerians in its neighbourhood and also has a rich abundance of Macrobrachium fishery.

\subsection{Sample Collection}

Quarterly sampling of Macrobrachium vollenhovenii, water and sediment was conducted on Asejire Lake, Southwest Nigeria, in the months of November, February and May. Water and sediment samples were collected from about $50 \mathrm{~m}$ off the shoreline. Water samples were collected about $50 \mathrm{~cm}$ depth below the water surface in pre-washed and acidified plastic bottles and immediately spiked with $1 \mathrm{ml}$ of nitric acid to prevent microbial activities. Sediment samples were collected with a plastic shovel into labeled pre-washed and acidified polythene bags. Samples of the freshwater prawn, $M$. vollenhovenii, were collected from fishermen/mongers. The prawns were washed with water to remove particles from their body and transported on ice packs to the Fisheries laboratory of Lagos State University. Thereafter, the collected prawn samples were divided into three (3) size groups viz small $(2.0-6.9 \mathrm{~cm} ; 8.02-17.05 \mathrm{~g})$, medium $(7.0-$ $11.9 \mathrm{~cm} ; 26.12-38.09 \mathrm{~g})$ and large $(12.0-16.9 \mathrm{~cm}$; $41.06-64.03 \mathrm{~g}$ ). The total length, to the nearest $0.1 \mathrm{~cm}$, and body weight, to the nearest $0.01 \mathrm{~g}$, of $M$. vollenhovenii were measured with a transparent plastic ruler and Mettler balance (PM 400) respectively.

\subsection{Digestion of Prawn, Water and Sediment}

Samples: Prawn samples were defrosted for $2 \mathrm{hr}$, weighed and oven-dried at $80^{\circ} \mathrm{C}$ until a constant dry weight was obtained. The dried prawn samples were grounded to a fine powder using mortar and pestle. $2 \mathrm{~g}$ of the ground samples was weighed out on the Mettler balance $(\mathrm{DM}-11-\mathrm{K})$ and put into an appropriately 
labelled beaker. Thereafter, $10 \mathrm{ml}$ of nitric acid $\left(\mathrm{HNO}_{3}\right)$ and $5 \mathrm{ml}$ of hydrogen-peroxide $\left(\mathrm{H}_{2} \mathrm{O}_{2}\right)$ were added to the sample in the beaker, and then the mixture was heated on the hot-plate to ignite as well as carefully burn the sample in the fume cupboard. The residue was then diluted with distilled water to make up to $20 \mathrm{ml}$ in the beaker. This procedure was repeated for each of the three size categories of the prawn and digestion of the air-dried sediment samples. $15 \mathrm{ml}$ of concentrated $\mathrm{HNO}_{3}$ was added to $25 \mathrm{ml}$ of water sample in a conical flask. This mixture was then heated on a hot plate until a clear solution was obtained. Thereafter, $5 \mathrm{ml}$ of dilute $\mathrm{HCl}$ was added to the clear solution and the mixture was made up to $30 \mathrm{ml}$ with distilled water and stored for analysis.

\subsection{Determination of Concentration of Heavy Metals}

The resulting solutions (prawn, water and sediment) from the digestion were then aspirated into the flame of the Atomic Absorption Spectrophotometer (AAS) Perkins Elmer Analyst 200 using air-acetylene flame for the metal analysis against metal solution. Each metal ( $\mathrm{Zn}, \mathrm{Cu}, \mathrm{Mn}, \mathrm{Pb}$ and $\mathrm{Cd}$.) was analyzed using the specific hollow cathode lamp at a specific wavelength. Analyses were replicated three times.

\subsection{Determination of Bioaccumulation \\ Factor}

The Bioaccumulation Factor (BAF), which is a measure of the ratio of the concentration of the substance in the study organism to that in the surrounding environment, was calculated as follows:

$$
B A F=\frac{\text { Concentration of Heavy Metal in Prawn }(\mathrm{mg} / \mathrm{kg})}{\text { Concentration of Heavy Metal in Water }(\mathrm{mg} / \mathrm{L})}
$$

\subsection{Statistical Analysis}

Descriptive statistics was used to analyse the data obtained from this study. Furthermore, the one-way Analysis of Variance (ANOVA) was used to analyse differences in concentration of metals in prawn tissues. The Chi-square test was used to compare the levels of heavy metals in $M$. vollenhovenii, water and sediment samples with the standards set by the Food and Agriculture Organization/World Health Organization. In all cases, the level of significance was set at $P=.05$.

\section{RESULTS}

The mean concentrations of heavy metals $(\mathrm{mg} / \mathrm{kg})$ in the various sizes of Macrobrachium vollenhovenii from Asejire Lake are presented in Table 1. There was no significant difference, at $P=.05$, among the values obtained for heavy metals concentrations in the different sizes of the prawns except in Cadmium which had significantly different values at $P=.05$ among the sizes. Amongst the various prawn sizes, Cadmium had the least concentration value while Zinc had the highest concentration value. In the different sizes of the prawn studied, the concentration values in $\mathrm{mg}$ of heavy metals per $\mathrm{kg}$ of the prawn specimens were in the following order: $\mathrm{Zn}>\mathrm{Cu}>\mathrm{Mn}>\mathrm{Pb}>\mathrm{Cd}$. Thus, irrespective of the prawn size, concentrations of the heavy metals followed the same order of decrease or increase. An overall ranking of the mean concentrations of metals in samples of the various prawn sizes followed this order:
Large $>$ Small $>$ Medium. Thus, on the overall, the largesize prawns accumulated the highest concentration of metals, while the medium-size prawns accumulated the least concentrations.

Table 1: Mean concentrations $(\mathrm{mg} / \mathrm{Kg})$ of heavy metals in different sizes of Macrobrachium vollenhovenii from Asejire Lake, southwest Nigeria.

\begin{tabular}{cccc}
\hline & \multicolumn{3}{c}{ Prawn Sizes } \\
\hline Metals & Large & Medium & Small \\
$\mathrm{Mn}$ & $88.31 \pm 5.23$ & $90.79 \pm 10.12$ & $85.22 \pm 3.40$ \\
$\mathrm{~Pb}$ & $8.21 \pm 1.24$ & $6.49 \pm 1.23$ & $7.75 \pm 1.04$ \\
$\mathrm{Cu}$ & $98.17 \pm 5.67$ & $96.68 \pm 4.14$ & $102.37 \pm 6.80$ \\
$\mathrm{Zn}$ & $105.31 \pm 2.40$ & $101.00 \pm 2.26$ & $103.12 \pm 4.01$ \\
$\mathrm{Cd}$ & $0.82 \pm 0.07^{\mathrm{a}}$ & $1.88 \pm 0.36^{\mathrm{b}}$ & $1.00 \pm 0.10^{\mathrm{c}}$ \\
\hline
\end{tabular}

Results from the analysis of heavy metals in water samples from Asejire Lake revealed the presence of three (out of the five) heavy metals studied (Fig. 1). The highest mean concentration recorded was for $\mathrm{Zn}(1.41$ $\pm 0.28 \mathrm{mg} / \mathrm{L})$ and the lowest was for $\mathrm{Pb}(0.13 \pm$ $0.25 \mathrm{mg} / \mathrm{L})$. Mean concentration value of $0.31 \pm$ $0.42 \mathrm{mg} / \mathrm{L}$ was recorded for $\mathrm{Cu}$, while the concentrations of both $\mathrm{Mn}$ and $\mathrm{Cd}$ were below detectable level in the water samples.

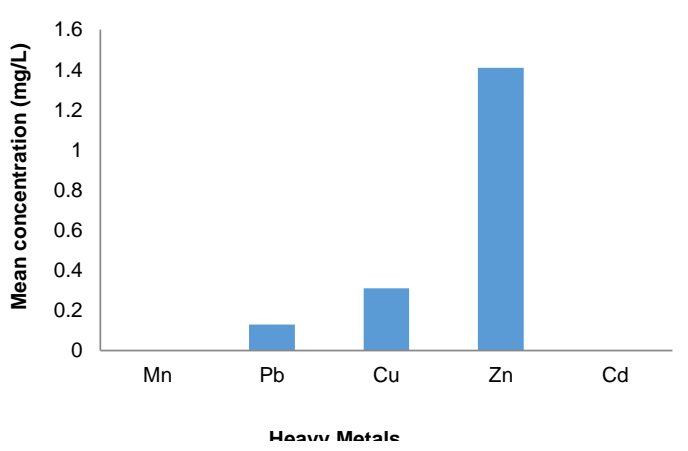

Figure 1: Mean concentration ( $\mathrm{mg} / \mathrm{L})$ of heavy metals in water samples from Asejire Lake, southwest Nigeria.

Figure 2 shows the concentration of heavy metals $(\mathrm{mg} / \mathrm{kg})$ in sediments from Asejire Lake. Zinc $(\mathrm{Zn})$ recorded the highest mean concentration value (1.80 \pm $0.14 \mathrm{mg} / \mathrm{Kg}$ ) while Cadmium (Cd) had the lowest value of $0.02 \pm 0.01 \mathrm{mg} / \mathrm{Kg}$. The mean concentration values for Manganese $(\mathrm{Mn})$, Copper $(\mathrm{Cu})$ and Lead $(\mathrm{Pb})$ were $0.83 \pm 0.05 \mathrm{mg} / \mathrm{Kg}, 0.58 \pm 0.11 \mathrm{mg} / \mathrm{Kg}$ and $0.53 \pm$ $0.10 \mathrm{mg} / \mathrm{Kg}$ respectively. 


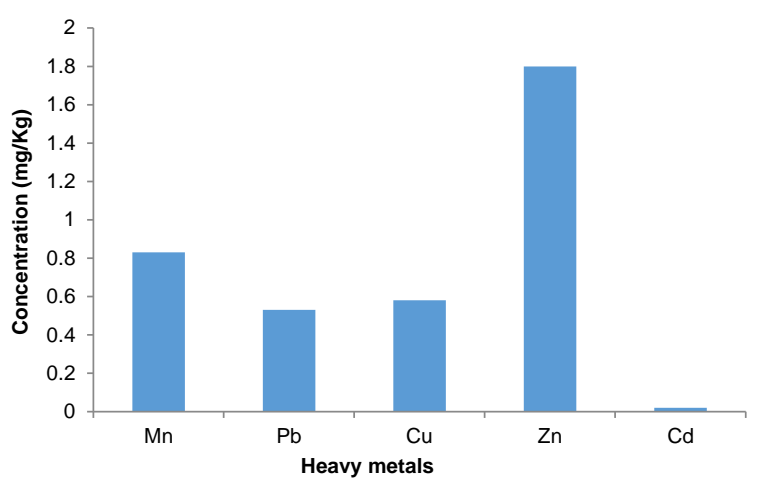

Figure 2: Concentrations $(\mathrm{mg} / \mathrm{Kg}$ ) of heavy metals in sediment samples from Asejire Lake, southwest Nigeria.

The bioaccumulation factors (BAF) of heavy metals analysed are presented in Figure 3. The highest bioaccumulation factor value of 330.23 was recorded for Copper in the small size of $M$. vollenhovenii while the least value (49.92) was recorded for Lead in the medium-size prawns. The BAFs for Copper $(\mathrm{Cu})$ were $316.68,311.87$ and 330.23 for the large, medium and small-size prawns respectively, while Zinc $(\mathrm{Zn})$ had values of 74.69 (large), 71.63 (medium) and 73.13 (small) and the respective values for Lead $(\mathrm{Pb})$ were 63.15, 49.92 and 59.62. This implies that $\mathrm{Cu}$ was the most bioaccumulated heavy metal in the prawns, followed by $\mathrm{Zn}$ and $\mathrm{Pb}$ in that order.

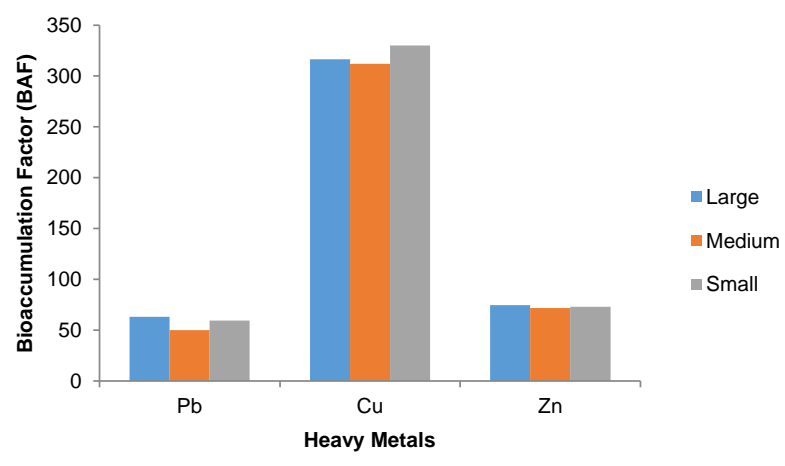

Figure 3: Bioaccumulation Factors (BAF) of Heavy metals in different sizes of Macrobrachium vollenhovenii.

\section{DISCUSSION}

Heavy metals naturally exist in the earth crust and they are persistent in nature with high half-life. When these metals exist at a considerable level, they form a part of the human diet and serve a variety of purposes in metabolic activities [19]. However, when these metals exist above tolerable levels in the body system, they become pathogenic and might consequently result in serious health consequences [20, 21, 22]. The etiology of renal, heart and endocrine diseases has been traced to the toxicity of heavy metals [23].

This study examined the concentration of selected heavy metals Manganese (Mn), Zinc $(\mathrm{Zn})$, Lead $(\mathrm{Pb})$, Copper $(\mathrm{Cu})$, and Cadmium $(\mathrm{Cd})$ in the tissue of Macrobrachium vollenhovenii from Asejire Lake, southwest Nigeria in relation to their body size (weight and length). The result of this study revealed that $\mathrm{Mn}$, $\mathrm{Zn}, \mathrm{Pb}, \mathrm{Cu}$ and $\mathrm{Cd}$ were all present, in different concentrations, in the body tissue of $M$. vollenhovenii, and this is in accord with the results of earlier studies [6, $12,19,24,25]$. From this study, Zinc had the highest concentration $(105.31 \pm 2.40)$ and Cadmium with the lowest concentration $(0.82 \pm 0.07 \mathrm{mg} / \mathrm{Kg})$ in the tissue of the $M$. vollenhovenii, as also reported by [24]. Similar findings have also been recorded in crustaceans [26, $27,28,29,30]$. Results from this study showed that the mean concentrations of $\mathrm{Mn}, \mathrm{Pb}, \mathrm{Cu}$ and $\mathrm{Cd}$ are above the maximum limits for marine sea food (100ppm) [31] and for prawn (1000ppm) [32], while the concentration of $\mathrm{Zn}$ was similar to the WHO limit [31], but less than the FAO limit [32].

In relation to the different sizes of prawns studied, the ranked mean concentration of heavy metals was in this decreasing order: Large > Small > Medium. In comparison to large animals, generally small animals concentrate more heavy metals. However, with the exception of Cadmium, the analysis of variance (ANOVA), at 95\% confidence level, revealed that there is no significant difference $(P=.05)$ in heavy metals concentration in relation to size in $M$. vollenhovenii, which suggests that there is no clear relationship between the body size and ability of the prawn to absorb heavy metals from the surrounding water. Concentrations of the various heavy metals studied were higher in the prawn samples than both in the water and sediment samples. This was also reported by [39] and could be attributed to dietary uptake, feeding habits and availability of pollutants.

The concentration of metals detected in water samples was in this order; $\mathrm{Zn}>\mathrm{Cu}>\mathrm{Pb}(1.41 \pm 0.28 \mathrm{mg} / \mathrm{L}, 0.31$ $\pm 0.42 \mathrm{mg} / \mathrm{L}, 0.13 \pm 0.25 \mathrm{mg} / \mathrm{L}$ respectively). This result also agreed with that of (17) in the same water body, except that Lead was not detected and the reported concentration values of $\mathrm{Zn}$ and $\mathrm{Cu}$ were a bit lower than that of this study, and this could be as a result of the continuous accumulation of these metals in the water body. The mean concentration values of $\mathrm{Cu}(0.31 \pm$ $0.42 \mathrm{mg} / \mathrm{L})$ and $\mathrm{Zn}(1.41 \pm 0.28 \mathrm{mg} / \mathrm{L})$ in water from Asejire Lake were below the WHO recommended maximum limits [33], while the mean concentration value of $\mathrm{Pb}(0.13 \pm 0.25 \mathrm{mg} / \mathrm{L})$ was above the maximum limit. Of the five metals detected in the tissue of $M$. vollenhovenii in this study, only three ( $\mathrm{Pb}, \mathrm{Cu}$ and $\mathrm{Zn}$ ) were detected in the prawn surrounding water; Cadmium and manganese were not detected. Cadmium was also not detected in the water samples in an earlier study on the same water body [34]. The reason could be that the metals that were not detected in water, but detected in the body tissue, entered the tissue of the prawns through the food they consumed from the sediment and not through water, since these two metals (cadmium and manganese) were detected in the sediment and the prawns are benthic feeders. The accumulation of heavy metals in organisms has been linked to direct uptake of these metals from food, respiration and the surrounding environment across the body wall [36]. The reason could also be that those metals that were not detected were not present or present at a very small concentration in the waste from 
agricultural activities and other industries that discharge their wastes into the water body, hence the metals exist at undetectable concentration in the water samples. Concentrations of the various heavy metals were lower than the values in the prawn specimens, as also reported by $[6,36,37]$.

The concentration of heavy metals in $\mathrm{mg} / \mathrm{Kg}$ of bottom sediment samples in Asejire Lake was in this decreasing order: $\mathrm{Zn}>\mathrm{Mn}>\mathrm{Cu}>\mathrm{Pb}>\mathrm{Cd}(1.80 \pm$ $0.14 \mathrm{mg} / \mathrm{Kg}>0.83 \pm 0.05 \mathrm{mg} / \mathrm{Kg}>0.58 \pm 0.11 \mathrm{mg} / \mathrm{Kg}>$ $0.53 \pm 0.10 \mathrm{mg} / \mathrm{Kg}>0.02 \pm 0.01 \mathrm{mg} / \mathrm{Kg}$ ). These values suggest that the mean concentrations of cadmium and copper in the bottom sediments are lower than the maximum limits in sediment samples of 10.00 and 250.00 respectively [38]. However, the fact that the mean concentrations of these metals in the sediment samples are lower than the values in the prawn tissues could imply a high rate of accumulation of these metals in the tissues of the prawns. Also, the concentrations of $\mathrm{Cu}, \mathrm{Zn}$ and $\mathrm{Pb}$ in the bottom sediment were higher than the concentrations in the water samples. Sediments have been variously reported to concentrate more heavy metals than the aquatic system [39, 40, 41]. This could be attributed to higher density of metals compared to that of water. Consequently, heavy metals tend to settle at the sediment where they accumulate at higher concentrations.

The concentration of heavy metals in the prawn tissue relative to the concentration in water (bioaccumulation) was calculated using the bioaccumulation factor (BAF). This factor measures the extent to which heavy metals are shared between an organism and the environment. The BAFs for $\mathrm{Cu}$ in the large, medium and small-size prawns were $316.68,311.87$ and 33023 , while the corresponding values for $\mathrm{Zn}$ were $74.69,71.63$ and 73.13; and for $\mathrm{Pb}$, the values were $63.15,49.92$ and 59.62. This study revealed that $\mathrm{Cu}$ was the most bioaccumulated in the different sizes of $M$. vollenhovenii studied, followed by $\mathrm{Zn}$ and $\mathrm{Pb}$. An overall ranking of the BAFs, in relation to size, showed that the large prawns bioaccumulated the most heavy metals while least bioaccumulation was in the medium prawns. Copper was reported to bioaccumulate in the shrimp, lobster and crab more than any other heavy metals investigated in the Oron River Channel [42]. This implies that $M$. vollenhovenii can be used to monitor the levels of these heavy metals in the water body.

\section{CONCLUSION AND RECOMMENDATIONS}

Macrobrachium vollenhovenii and water samples from Asejire Lake, from this study, recorded mean heavy metals concentration values above the maximum limits recommended by WHO/FAO. The prawns bioaccumulated these metals from the surrounding environment. Therefore, the results suggest that prawn and water from this water body are not safe for human consumption/use until proper managerial policy is put in place to check the influx of these heavy metals into the Lake. There is the need for close monitoring of the environment of this Lake in order to possibly control the discharge of agricultural/domestic wastes into the Lake.
This becomes necessary in view of the hydrological importance of this Lake to the people and the likely consequences of the transfer of potentially toxic metals from the water to man.

\section{COMPETING INTERESTS}

Authors declare that no competing interests exist.

\section{AUTHORS' CONTRIBUTIONS}

AAJ designed the study, performed the statistical analysis and participated in the discussion of the findings. AO collected the samples and prepared manuscript while RAO handled the analysis of heavy metals. All authors participated in the preparation of and approved the final manuscript.

\section{REFERENCES}

1. Obodo GA. The bioaccumulation of heavy metals in fish from Anambra River. J. Chem. Soc. Nigeria. 2004: 29: 60 - 63 .

2. Olowu RA, Ayejuyo OO, Adejoro IA, Adewuyi GO, Osundiya MO, Onwordi CT, Yusuf KA, Owolabi MS. Determination of heavy metals in crabs and prawns in Ojo River, Lagos, Nigeria. E-J. Chem. 2010: 7(2): 526530.

3. Funtua MA, Hamzat LA, Dailami SA, Onakpa SA. Heavy metal contents of Water, Sediment and Fish from Kpatariver Lokoja, Kogi State-Nigeria. International Journal of Environmental Science and Toxicology Research. 2016: 4(9): 162 - 168.

4. Al-Shawi AW, Dahl R. The determination of cadmium and six other heavy metals in nitrate/phosphate fertilizer solution by ion chromatography. Anal Chem Acta.1999: 391(1): $35-37$.

5. Charis KB, Abassi SA. A Study of the Fish Fauna of Oussudu - A rare freshwater lake of South India. International Journal of Environmental Studies. 2005: 62(2):137- 145.

6. Nsofor $\mathrm{Cl}$, Igwilo IO, Ikpeze OO, Ikeogu CF, Umeoguagu FO, Okonkwo CJ. Bioaccumulation of heavy metals in shellfish, Macrobrachium rosenbergii, in Niger River at Onitsha, Anambra State, Nigeria. Inter J Agri Biosci. 2014: 3(1): 38 - 40.

7. Dirican S, Çilek S, Çiftçi H, Bıyıkoğlu M, Karaçınar S, Yokuş A. Preliminary study on heavy metal concentrations of Anatolian Khramulya, Capoeta tinca (Heckel, 1843) from Çamlıgöze Dam Lake, Sivas, Turkey. Journal of Environmental Health Science and Engineering. 2013: 11 (7): 1-6.

8. Jimoh AA, Clarke EO, Ndimele PE, Kumolu-Johnson $\mathrm{CA}$, Adebayo FA. Concentrations of heavy metals in Macrobrachium vollenhovenii (Herklots, 1857) from Epe Lagoon, Lagos, Nigeria. Research Journal of Environmental and Earth Sciences. 2013: 3(3):197 202.

9. Oyewo EO. Industrial sources and distribution of heavy metals in Lagos Lagoon and their biological effects on estuarine animals. Ph.D Thesis, University of Lagos, Lagos State, Nigeria. 1998: 250pp. 
10. Gore JA, Bryant RM. Changes in fish and macroinvertebrate assemblages along the impounded Arkansas River. J. Freshw. Ecol. 1986: 3: 333 - 338. 11. Abou-Zaid FA, El-Serafy S, Shourbagy IK. The toxicity of copper and zinc to three fish species of genus Tilapia. Egypt J. Appl. Sci. 1988: 3: 8-16.

12. Lee WP, Payus C, Mohd Ali SA, Vun LW. Selected heavy metals in Penaeus vannamei (White prawn) in aquaculture pond near Likas Lagoon, Sabah, Malaysia. International Journal of Environmental Science and Development. 2017: 8(7): 530 - 533.

13. Kennish MJ. Practical handbook of estuarine and marine pollution, Boca Raton. FL, CRC: 1996: 524pp.

14. Obasohan EE. Bioaccumulation of chromium, copper, manganese, nickel and lead in a freshwater cichlid, Hemichromis fasciatus, from Ogba River in Benin City, Nigeria. African Journal of General Agriculture. 2008: 4(3): 141 - 152.

15. Amin MN, Begum A, Mondal GK. Trace Element Concentrations Present in Five Species of Freshwater Fish of Bangladesh. Bangladesh Journal of Scientific and Industrial Research. 2011: 46(1): 27-32.

16. Holthius LA. FAO Species Catalogue. Vol. 1 Shrimps and Prawns of the World (An Annotated Catalogue of Species of Interest to Fisheries. FAO Fisheries Synopsis 25: 1980: 261pp.

17. Bossche V, Bernacsek GM. Source book for the inland fishery resources of Africa Vol. 2. CIFA Technical Paper CIFA/T18 Vol. 2. 1990: 423.

18. Mackay D, Fraser A. Bioaccumulation of Persistent Organic Chemicals: Mechanisms and Models. Environmental Pollution. 2000: 110: 375-391.

19. Kamal T, Tanoli MAK, Mumtaz M, Ali N, Ayub S. Bioconcentration Potential Studies of Heavy Metals in Fenneropenaeus penicillatus (Jaira or Red Tail Shrimp) along the Littoral States of Karachi City. Journal of Basic and Applied Sciences. 2015: 11:611-618.

20. Mallampati SR, Bhavesh M, Sunil D, Manish J, Leena K, Venkatrama KSS, Shaik B, Gadde R, Prashant B. Bioaccumulation of heavy metals in some commercial fishes and crabs of the Gulf of Cambay, India. Current Science Journal. 2007: 92 (11): 14891491.

21. Akpor O B, Muchie M. Remediation of heavy metals in drinking water and wastewater treatment systems: Processes and applications. International Journal of Physical Sciences. 2010: 5 (12): 1807-1817.

22. Phuong TTM. Bioaccumulation of heavy metals in Nha Trang Bay, Khanh Hoa, Viet Nam. Earth Sciences Universitiē Nice Sophia Antipolis. Ph.D Thesis. 2014: 265pp.

23. Chailapakul O, Korsrisakul S, Siangproh W, Grudpan K. Fast and simultaneous detection of heavy metals using a simple and reliable microchipelectrochemistry route: An alternative approach to food analysis. Talanta. 2008: 74: 683-689.

24. Okocha RC, Adedeji OB. Heavy Metal Concentrations in Prawns (Macrobrachium vollenhovenii) and Water from Asejire River Southwestern Nigeria. Advances in Environmental Biology. 2011: 5(6): 1359 - 1363.

25. El Gendy A, Al Farraj S, El Hedeny M. Heavy Metal Concentrations in Tissues of the Shrimp Penaeus semisulcatus (De Haan, 1844) From Jazan, Southern
Red Sea Coast of Saudi Arabia. Pakistan J. Zool. 2015: 47(3): $671-677$.

26. Mitra A, Barua P, Zarman S, Banerjee K. Analysis of Trace Metals in Commercially Important Crustaceans Collected from UNESCO Protected World Heritage Site of Indian Sundarbans. Turkish Journal of Fisheries and Aquatic Sciences. 2012: 12: $53-66$.

27. Hossain MS, Khan YSA. Trace Metals in Penaeid Shrimp and Spiny Lobster from the Bay of Bengal. Science Asia. 2001: 27: 165-168.

28. Miramand P, Guyot T, Rybarczyk H, Elkaim B, Mouny P, Dauvin JC. Contamination of the Biological Compartment in the Seine Estuary by $\mathrm{Cd}, \mathrm{Cu}, \mathrm{Pb}$ and Zn. Estuaries. 2001: 2(4): 1056 - 1065.

29. Tyrrell L, Mchugh B, Glynn D, Twomey M, .loyce E, Costello J, Mcgovern E. Trace Metal Concentrations in Various Fish Species Landed at Selected Irish Ports. Marine Environment and Health Series. 2005: 20: 1-19. 30. Mitra A, Mondal K, Banerjee K. Concentration of Heavy Metals in Fish Juveniles of Gangetic Delta of West Bengal, India. Research Journal of Fisheries and Hydrobiology. 2010: 5(1): 21-26.

31. World Health Organization. Heavy metals environmental aspects. Environmental Health Criteria. No. 85. 1989: Geneva, Switzerland.

32. Food and Agriculture Organization. FAO/WHO Food Standard Programme. 2nd ed. Codex Alimentarius Commission. 1992: 1: 114-190.

33. World Health Organisation. Guidelines for Drinking Water Quality (2nd Edition). Volume 3. Surveillance and Control of Community Supplies. Geneva, Switzerland. 1997.

34. Jenyo-Oni A, Oladele AH. Heavy Metals Assessment In Water, Sediments And Selected Aquatic Organisms In Lake Asejire, Nigeria. European Scientific Journal. 2016: 12(24): $339-351$.

35. Heip C. Benthic studies summary and conclusions. Marine Ecology Progress Series. 1997: 91: 265 - 269. 36. Davies O A, Allison ME, Uyi HS. Bioaccumulation of heavy metals in water, sediment and periwinkle (Tympanotonus fuscatus var radula) from the Elechi Creek, Niger Delta. African Journal of Biotechnology. 2006: 5(10): 968 - 973.

37. Fabris JA, Richardson BJ, Sullivan JF, Brown FC. Estimation of Cadmium, Lead and Mercury concentrations of Estuarine Waters using the Mussel Mytilus edulis planulasus. Inter J Envir Toxicol, 1994: 9: 183-192.

38. Food and Agricultural Organisation. Compilation of legal limits for hazardous substances in fish and fishery products. FAO Fishery Circular, 464. 1985: 5-100.

39. El Gammal, MA, Al-madan A, Fita N. Shrimp, Crabs and Squids as bio- indicators for heavy metals in Arabian Gulf, Saudi Arabia. International Journal of Fisheries and Aquatic Studies. 2016: 4(6): 200 - 207.

40. Zyadah MA, Almotairy M. Evaluation of environmental pollution in the Arabian Gulf Coast at the Eastern Province, SA. ATBAS. 2012: 2(3): 14 - 21.

41. Adeniyi AA, Yusuf KA, Okedeyi OO. Assessment of the exposure of two fish species to metals pollution in the Ogun River, Ketu, Lagos, Nigeria. Environ Monit Assess. 2008: 137: 451-458.

42. Iwuoha GN, Onojake MC. Bioaccumulation of Heavy Metals in Crustaceans from Oron River Channel,Osung Area Oron-City, Akwa-Ibom, Nigeria.J. Chem. Soc. Nigeria.2016: 41(1): 33-35. 